\author{
Michał Suszczewicz \\ mgr \\ Zakład Geografii Społeczno-Ekonomicznej, \\ Uniwersytet Wrocławski \\ Michal.suszczewicz@uwr.edu.pl
}

DOI: 10.35117/A_ENG_17_01_05

\title{
Youth and transport on the periphery - the image and using of local passengers transport of young people journey in Wschowa county (Lubuskie Voivodeship)
}

\begin{abstract}
The article is a view of transport from young people point from peripheral area, located out of reach the agglomeration communication system. The research analysis based on survey shows what elements of passengers carriers are the most important in young's people journey from main city or other localities preferences. The conclusions indicate that the intensity of this group journeys is based on transportation net and frequency of bus courses relate with settlement network (near big towns), not with recently administrative division. The article shows the inequality of journeys from main city and other locations, the process of deregulation in local passengers transport market and progressive disproportion in transport accessibility in that peripheral region.
\end{abstract}

Keywords: Passengers transport; Transport accessibility; Transport preferences

\section{Introduction}

The main aim of the article is to present the perception of local transport service providers [15] and the preferences of secondary school students from the peripheral district, outside the agglomeration of the transport service in the western part of Poland. The hypothesis presented by the author in this article is as follows: The frequency and availability of transportation carriers' courses directly affects the frequency of travel of youth in the Wschowa region, regardless of the current administrative divisions. As part of local transport research, a survey was used to examine a group of young people attending one of the general secondary schools in Wschowa. The study involved two groups of people. The first one comes from the village on the border of the lubuskie, wielkopolskie and dolnośląskie provinces. The second respondents are residents of the town of Wschowa, the capital of the district. Such a division of the respondents is motivated by the fact of showing differences or similarities in the perception of transport by the inhabitants of the city and the surrounding towns. The surveyed area was selected not by accident, due to the specific arrangement of transport connections which binds the poviat to a very limited extent with other localities in the Lubuskie province, as compared to the neighboring provinces [13]. The analysis is strongly linked to the study of transport accessibility aspects of peripheral locations, which can strongly influence the choice of means of transport [6]. This applies both to spatial and temporal availability [10].

The article consists of a discussion of the survey methodology, a brief description of the local transport in the region, a detailed description of the results of the survey and an analysis of the responses from respondents. This study is of local character, however, it shows the important problem of shaping and activity of passenger carriers in the peripheral area, not directly connected with the transport service of the agglomeration.

\section{Methodology of research}

Surveys conducted in the first half of 2012 show the assessment of local passenger transport in and around Wschowa. As a study group, 87 high school students from I, II and III class I 
were selected. Tomasz Zana in Wschowa (1/3 of all students at school). Surveys included opinions of students living in Wschowa (38 people) and neighboring towns from neighboring communes (Sława, Szlichtyngowa - Lubuskie province, Wijewo, Przemęt - Wielkopolskie Province) (Fig. 1

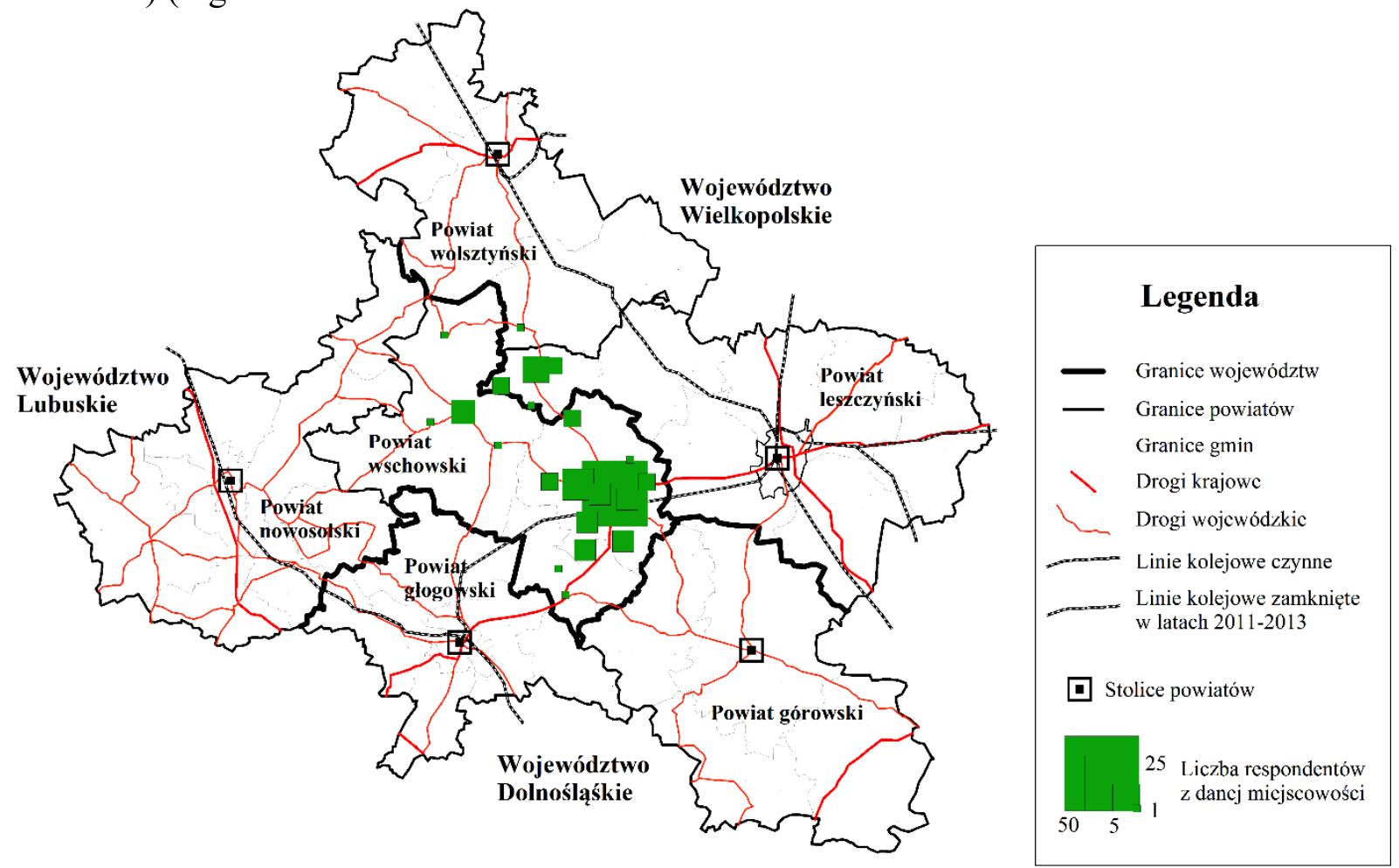

1. Village spatial distribution of respondent's origin and the administrative-transport characteristics of the region. Source: own work.

The questionnaire consisted of two parts: the first included a personal questionnaire along with information on commuting to the city (the question was answered only by non-Wschowa residents), while the second part consisted of questions related to the availability of passenger connections with larger towns. The purpose of this study was to assess the ratings of passenger companies and the transport preferences of the youth in the outlying area, where transport related to metropolitan service is of little importance. The enterprises assessment consisted in giving adequate values for the availability of passenger courses, the image of the carrier (quality of rolling stock, price and transit time). Transport preferences were defined as directions that youth chooses, under their cultural, social, or other needs; which cannot be realized in the capital of the county, or in the nearby village of origin.

\section{Characteristics of transport in Wschowa county}

The surroundings of the Wschowa city are very diverse, both when it comes to the formation of the area, the history and characteristics of the local community living in the area, which significantly influences the travel direction [13][14]. Wschowa, according to the administrative division, is located in Lubuskie province, however, the region has very strong economic and historical connections with major urban centers, which are nearby Leszno and Głogów, which belong to neighboring provinces.

Wschowa county is an unusual administrative unit. It was created only in 2002 , due to the disconnection of 3 communes (Wschowa, Sława and Szlichtyngowa) from the at the time Nowy Sącz county. The county has only three municipalities, which before the last general administrative change made in 1999, belonged to two separate provinces (Zielonogórski and Leszno). The county currently has about 39,000 inhabitants. The area covered before World 
War II was the border between Poland and Germany; and before the partition, between the Commonwealth and the Kingdom of Prussia. All these elements made the district wschowski today has a very specific passenger route network, which is characterized by residual passenger courses with other towns located in the current lubuskie province. This is very visible in the case of directions of passenger service - the connections serving the Wschowa region with the above centers are more frequent and convenient (mainly through direct connections) than courses to other similar sizes and significance of cities located in Lubuskie province (to which only connections with transfers are made). This transport network and transport spatial availability in this micro-region are very clearly reflected in the transportation preferences of the young people. Passenger transport within the district is currently restricted to circular routes, namely PKS transport (by bus) and private minibuses. In the first case there are two companies operating in the district: "Milla" (formerly PKS Leszno) and "Intertrans" Głogów. Both companies run courses connecting most of the district with Wschowa. At a minimum, local traffic also supports single bus routes of bus operators Jelenia Góra PKS, Słupsk PKS. The minibuses carriers ply mainly between Łodz and Głogów through Wschowa and Szlichtyngowa, as well as from Wschowa to Sława and until recently with single courses to Poznań. There are also courses from Sława to Głogów, Poznań, Leszno, Nowa Sól and Zielona Góra [2], update .www.e-podroznik.pl, at 5/31/2016). Most courses take place during the school year or on weekdays (Monday to Friday), weekend calls only include selected courses to major cities of the region. A bit different with the minibus carriers, the courses are held from Monday to Friday as well as at weekends. There were several railroads in the county a few years ago [2]. Currently, passenger traffic on the only active railway from Głogów to Leszno via Wschowa is suspended. The modernization and electrification of the route are planned, which may result in the reactivation of passenger rail traffic in the area of the examined county [12].

\section{Perception of local transport by high school students}

The time of the respondents arrival to Wschowa was varied and depended mainly on the remoteness of the given origin of the respondent from Wschowa. The study group of high school students coming from out of town frequently commuted to the city in time to 30 minutes $(61 \%$ total). Sometimes this time was extended to over 60 minutes, in the case of people commuting from very distant places (e.g. Kaszczor, Ciosaniec - $30 \mathrm{~km}$ to Wschowa). Most of the people (57\%) commuted by their own car (traveling by car alone or with parents who commute to the city)). The remaining group of people use other means of transport, among which dominate bus travel Leszno Milla / Głogów Intertrans (47\%). A little over 10\% of respondents also used the service of microbuses carriers. For most people the transport is not burdensome (the answers: rather not $-33 \%$, definitely not $-18 \%$ ), but on this result has a great impact the rating of people commuting by car. The elements most affected by the negative assessment of local passenger transport are presented in the diagram below (Fig.2) 


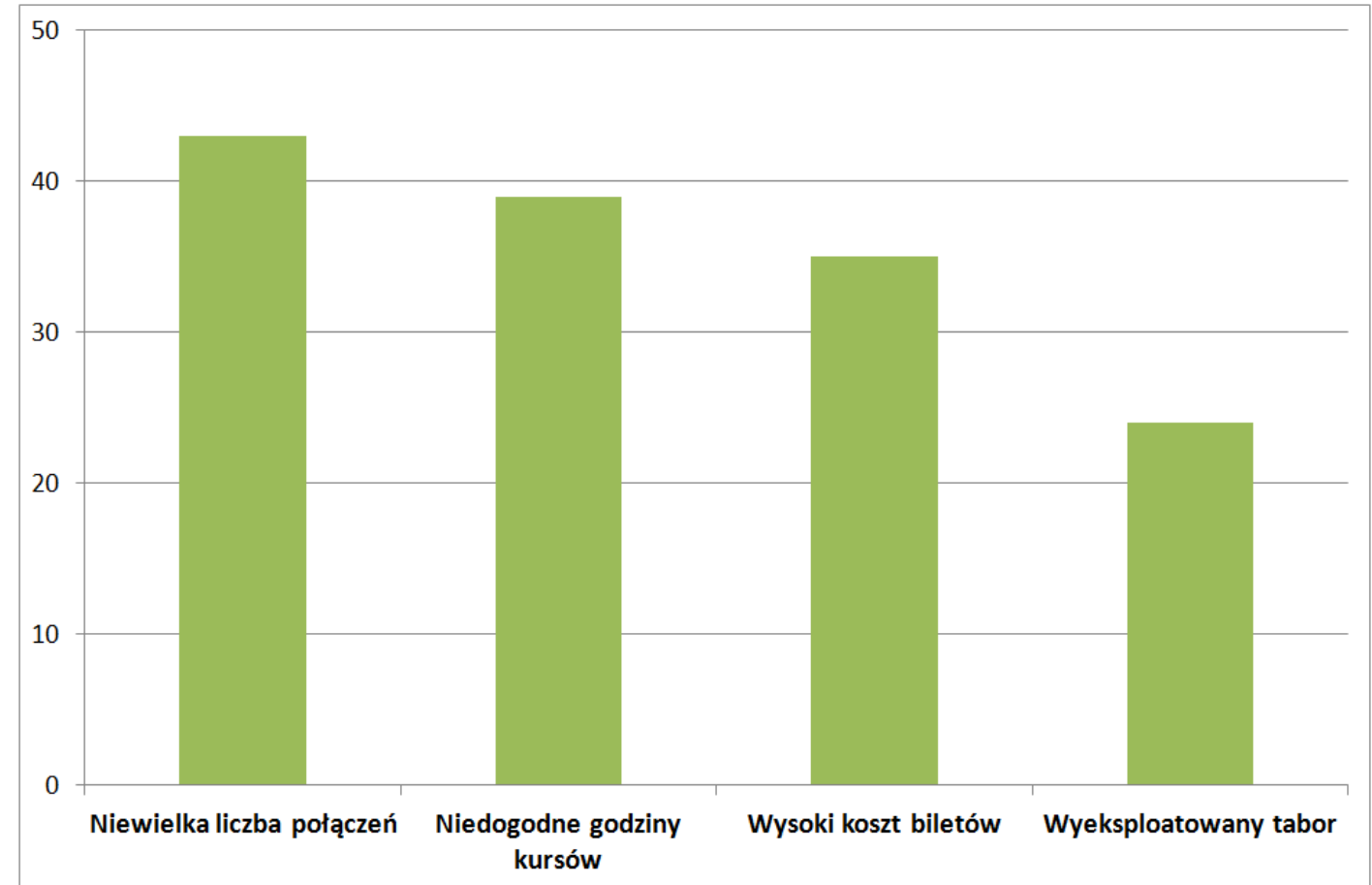

2. Factors that have negative impact on the assessment of the transport services quality indicated in the survey by youth. Source: own work.

The above answers are very clearly reflected in passenger transport reality. Most courses from Wschowa bus station are during working days of the week. On days off, holidays or holiday breaks, the courses are not frequent and mostly combine with Wschowa, Leszno, Głogów or other major cities. Weekend breaks with local villages are also limited, including only villages that are located alongside routes leading to bigger towns. The frequency of courses is adjusted to the school year and organization of work in local businesses. This reduces the number of courses to morning transits around 7:00 (towards the city) and afternoon return around 14: 00-16: 00 (from the city). In the remaining hours the courses are not carried out, which forces the passengers to wait until the departure time of the bus, or eventually to search for another means of transport to get to their place. Very clearly highlighted by the respondents was the lack of access to the village in the evening or night. Interestingly, the respondents despite the possibility of choice, very rarely marked the problems associated with time travel to the city or cases of delays on the route. This indicates the real speed of the courses and the reliability of the local carriers as part of their services.

The next part of the questionnaire pointed out the preferences of high school students. The respondents were able to determine the frequency of their trips to Leszno and Głogów (local bigger cities), Zielona Góra, Poznań and Wroclaw (the nearest regional centers of Wschowa). The first group of cities is important because of its importance and role in shaping the local cultural sphere (cinema, thriving cultural centers, numerous cultural events) and shopping (the presence of brand shops, shopping centers) or the place of residence of peers or families. The second group is the city that the high school students visit for similar reasons, but in comparison to local centers, the level of services and events is much higher (Fig.3). 


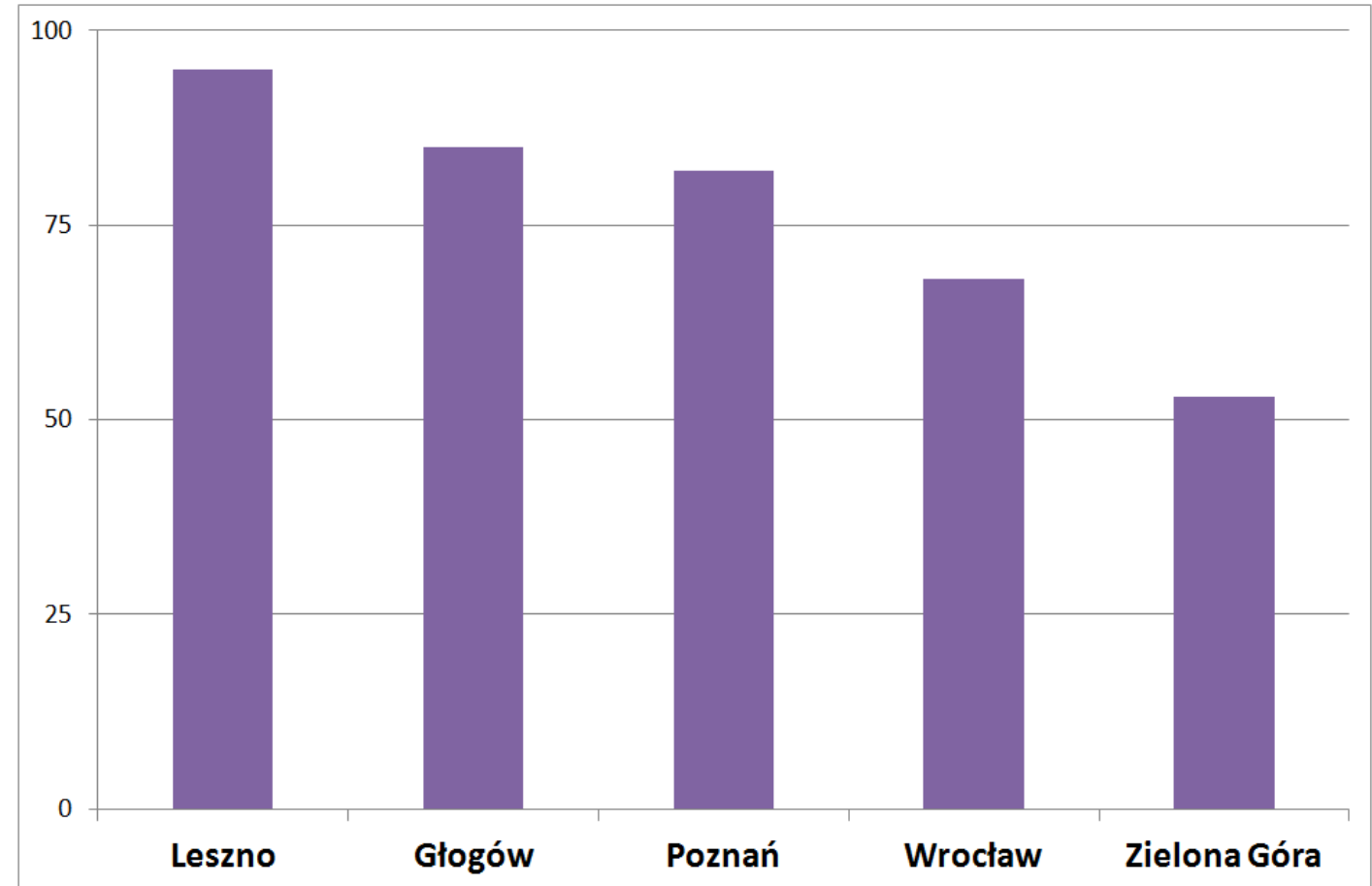

3. The share of respondents visiting medium and large urban centers. Source: own work.

The youth from the village in the vicinity of Wschowa most often chose Leszno from among the cities of the first group. More than half of the people were in this city at least a few times a month. In this city, the high school students mostly came by car ( $86 \%$ of visitors). To a lesser extent, they used private carriers (PKS - 27\%, private carriers - 7\% commuters).

A similar situation is associated with the second city - Głogów. However, it is worth mentioning here that the distance between the majority of the places from which the respondents came from, and Głogów is much higher than in Leszno, which was less frequent. Most, because as many as $65 \%$ of high school students arrived in this city not more than once a month. The rest of the respondents were equally (about 17\%), never in the city or more than twice a month. Almost all of the visitors came to the city by car (98\%).

The second group of cities of regional importance is opened by Zielona Góra, one of the capitals of Lubuskie Province. Within the research group of high school students, almost every second (47\%) was never in it. The rest of the respondents visited Zielona Gora sporadically, several times a year. As in the case of Głogów, almost all of them traveled to Zielona Góra by car.

Another regional center was Poznan. It is the closest urban agglomeration to the district of Wschowa. 2/3 of the respondents traveled to Poznan at least several times a year. As a part of the trip to the city, the high school students usually chose a car (over $85 \%$ ). In the case of a trip to Poznan and the next of the studied agglomerations - Wrocław, high school students also chose a car with a change to another means of transport. Usually it was a railway connection, which was selected by every fifth high school student out of the county capital. In the case of Wrocław, high school students outside Wschowa travel there less frequently than to Poznan. Every second of the surveyed high school students in the capital of Lower Silesia travels less often than once a month. Most of the high school students travel to Wrocław by car (72\%). Secondary school students use interchange courses on railways $(24 \%$ of respondents)). 
In the case of high school students from Wschowa, a slightly different attitude and evaluation of local transport can be noted, which is clearly highlighted in the responses to questions asked in the survey.

Leszno was chosen as the city to which each of the respondents living in Wschowa traveled (fig.3). Most of the high school students visited Leszno several times

in a month ( $2 / 3$ of respondents). Compared to the surrounding areas, the high school students from Wschowa visited them more often. People traveled there by car most often $(74 \%$ of responses), but an important role in getting to this city also meet the minibus connection ( $31 \%$ of respondents) and buses $(26 \%)$.

When it comes to the second local larger city - Głogów, commuting was less frequent than in Łódź. More than half of high school students went to this center less often than once a month. As the means of transport most often was indicated - a car (88\%), less frequent - mini bus connections (18\%), and occasionally - bus services $(6 \%)$.

The next group of comparable province cities in terms of the frequency of commuting from the vicinity of Wschowa varies considerably. Quite often people traveled to other large urban agglomerations - Poznan and Wroclaw. The first one was visited by almost all respondents. Usually, these trips were less frequent than once a month (85\%). Worth mentioning is the way of traveling to this city. Of the traditional means of transport on the whole route - the car was used in this category only by half of the high school students. Almost $60 \%$ of respondents chose a combined journey, with a change from a car to a train. Few people also chose bus or microbus connections (respectively $9 \%$ and $3 \%$ answers).

The next city to be compared was Wrocław. As in the case of Poznań, the majority of people $(67 \%)$ was going to this city less than once a month. The percentage of people who never visited this city was higher (23\%). Mostly people travelled to Wrocław by car $(73 \%)$, quite often the answer was - mixed journeys with change to arail (43\%).

The last major regional center was Zielona Góra, which is not often visited by high school students from Wschów. According to the responses trips to this city were made less frequently than once a month. The remaining respondents were never in the capital of their province. Those who traveled to Zielona Góra mostly used the car $(95 \%)$ or travelled with a change to train (10\%). Bus services have been used intermittently $(5 \%)$.

Respondents in the framework of local trips to larger cities, mainly chose to travelling by car. This was usually related to the ease, the speed of the journey and the availability of this means of transport, especially in rural areas. On the other hand, in many cases it was the only possibility of leaving the place. Among the surveyed high school students traveling with their parents, the aspect of choosing different types of travel to Wschowa was often raised, depending on the situation in which the people were found. For example, when a person travelled alone to school in Wschowa, the parents gave him/her a lift. However, when the same person traveled with his/her peers, he/she chose public transport, but the frequency of these trips was already considerably less frequent.

Due to the rare frequency of bus routes from smaller townsIn the vicinity of Wschowa, a large number of people traveled to larger cities by car. This fact is fully understandable, due to the need to transfer in Wschowa, generating additional costs and length of travel time. Sometimes such a decision was due to rare connections, or the total lack of them, which forced the use of their own means of transport. Due to differences in the age of the respondents (a large proportion of people under 18 years old), it was very clear that the choice of means of transport was between the people who had and did not have their own driving license. The majority of people aged 18 and over, at the time of the study, was using a car. The rest of the respondents used public transport. From the statements of some high school students can be concluded that when they reach the age of 18 and get a driving license, they 
also decide to travel with their own car. This is closely related to the perception of quality and availability of local transport.

The transport connections between Wschowa, Głogów and Leszno are y more than half of high school students sufficient (55\% for localities, $67 \%$ for Wschowa). Those who participated in the survey also pointed to the negative aspects of travelling by transport, theses were: quite high ticket prices and lack of courses in the late evening and on holidays. The above negative opinions were emphasized both by people outside of Wschowa as well as from the city.

The next element that was examined was Wschowa's traffic barriers. According to respondents' responses to the questionnaire, the biggest problem of the city is the small number of connections with other urban centers $(61 \%$ residents of Wschowa area, $46 \%$ Wschowa's inhabitants). Moreover, the travel time to bigger cities (46\% of people from Wschowa) or the cost of travel (27\% of people outside the city) was negatively assessed. In addition, some people from both Wschowa and surrounding area, raised the issue off the city from the rail passenger network.

According to the respondents, the improvement of local transport could be made by increasing the number of courses to smaller towns, reducing ticket prices and modernizing rolling stock. An important aspect emphasized mainly by high school students from Wschowa was the increase in the frequency of calls on school and work days. According to the respondents, the most important initiative that could improve the city's transport accessibility would be reactivation of railway connections. Behind this issue spoke almost half of the respondents (slightly under $40 \%$ of Wschowa population, $43 \%$ residents of the surrounding area).

\section{Conclusions from the survey responses analysis}

From the answers we can deduce some important comments concerning the use and evaluation of local transport in the trips of high school students from the periphery of the border regions of Lubuskie, Wielkopolskie and Dolnośląskie. First, while traveling outside the place of residence, the use of the car dominates. This is particularly evident in places with a small number of bus or minibus courses. The choice of a car for travel from these locations is justified because of the inability to use alternative public passenger transport outside the peak times. Similar conclusions about the impact of transport on areas threatened by social exclusion are presented in A. Mężyk's article [9]. Another very strongly distinctive aspect is traveling by car, as a sign of independence and maturity of the person's age. On the other hand, owning a car is currently not synonymous with prosperity and the necessity of having it in modern households [3] [8]. The clear distinction between the respondents is the age of 18, when it becomes possible to approach the B category driving test, which allows the driver to drive a car. At the age of 18, high school students can become independent from using public transportation courses, choosing a car for their trip to school or other places mentioned in the study. On the other hand, obtaining a driver's license allows the inhabitants of smaller towns to travel to other destinations, trips are not limited to the range of local transport companies. Unfortunately, this also results in lower profitability in the delivery of courses to smaller towns, especially those located far from the main routes where most courses are conducted [7]. In fact, the carriers limit their traffic to these locations, leading to a situation where the only way to travel beyond its borders is to own a car [9]. Public transport has a greater significance in the context of youth travel outside the city, which is recorded among the Wschowa inhabitants, due to the numerous courses connecting the town of Głogów and Leszno, the frequency of which is less dependent on particular days of the week. This shows that, despite the possibility of using their own car, to a large extent the youth benefit from collective transport as part of these trips. 
Another factor highlighted in the respondents' answers is the persistent economic and cultural impact of the larger cities outside Lubuskie, namely Głogów and Leszno. Despite the Leszno province liquidation in 1999, the importance of Leszno in the local labor market, services and entertainment is still very high. This is expressed among others in high school students journey, who point Leszno most often as a larger city of the first choice they travel to because of the above-mentioned objectives. The existence of a developed network of courses for this city, conducive to free travel both to the peaks and the inhabitants of other towns located on the route bus and minibus. Another city to which high school students often go, but less often than Leszno is Głogów. This city is mainly for people coming from the town located in the western part of the county, because of proximity, more convenient and faster connections and slightly lower travel costs in comparison with courses to Leszno.

An important problem resulting from the survey is the frequency of high school students' trips to regional administrative centers. Some of the participants in the study pointed to the capital of the Lubuskie province of Zielona Góra as a city to which they travelled several times. Despite a distance of about $70 \mathrm{~km}$ from Wschowa, almost every second high school student from the Wschowa district and the surrounding area, has never been there. The remaining group of people visited this city relatively rarely. This is probably due to the relatively weak economic impact of this city on the surroundings of Wschowa. It is worth adding that the only hasty connections between Wschowa and Zielona Góra were liquidated in 2016, which made it much more difficult to travel long distances without having to move in other cities. The attractiveness of the city's potential is similar to the surrounding larger towns, so the interest in traveling to Zielona Góra as a youth travel from the vicinity of Wschowa is limited. In the above study, students were not asked about travel to the capital of the province - Gorzów Wielkopolski, probably the answers about the frequency of trips to this city would be even more negative.

This situation indirectly illustrates the artificiality and arbitrariness of the territorial division implemented in the case of the Wschowa poviat. It is not reflected in the real directions and demand for passenger transport and does not affect the frequency of travel of young people. This situation is caused by occasional courses and quite high ticket prices, which connect the individual towns of Zielona Góra. The above factors also clearly discourage other potential travelers from traveling to this city. The example of Wschowa and the poviat of Wschowa shows how different is the demand for passenger transport and administrative affiliation.

The issue of travel to larger agglomerations such as Poznań and Wrocław looks a bit different than in the case of the current capital of the province. Both cities are much more attractive to high school students compared to Zielona Góra, which explains the greater frequency of trips to these centers. Usually, the whole trip to these cities was done solely by car. Among the respondents there was a large group of people who used a intermodal journey consisting of traveling partially by car or bus / minibus and later at the destination by train from Leszno. This is probably due to the lesser total cost of travel (which is significantly influenced by the $37 \%$ discount for students), which is lower than direct bus travel or car travel or total travel time currently on such journeys limited to $2 \mathrm{~h}$. Very wide range of courses every day of the week between Wschowa and Leszno, then between Leszno, Poznań and Wrocław, positively affects the frequency of trips to these cities.

Another aspect is the good assessment of the frequencies of Wschowa with Leszn and Glogow, while at the same time insufficient number of courses linking the city with smaller towns in the vicinity, located on the edge of the main routes. On the one hand, such a state of exchange rate is influenced by the economic factor. The courses are performed on the most profitable and frequented routes between cities. In smaller venues, courses are usually only available on weekdays, in the morning or in the afternoon. This is an unfavorable situation for 
people living in smaller towns, because of the problem of access to bigger cities outside the aforementioned hours, or in days off from work and school. This is the case when, during leisure time, the most attractive tourist areas of a county or region can not be reached by public transport as regular courses are not provided. The way out of this situation would be to introduce new courses between the villages during holiday, summer, as is the case in other Polish regions attractive for tourists carried out by local minibuses companies (Bieszczady Mountains, Coast, Masuria Lakes Region). This would improve the transport accessibility of the region during the holiday season, while also allowing tourists to enjoy other attractions outside of the destination where they are staying. Currently, during the holiday season the only means of transport is car.The last issue related to local transport in the vicinity of Wschowa is the aspect of passenger rail connections. Although it has been a year and a half since the elimination of passenger railroads, the local authorities have been strongly convinced that the decision of the Lubuskie Regional Transport Authority was not right. Similarly, in 2013, the county councilors voted in favor of a special position on the matter [4]. The railway in Wschowa has been functioning for more than 150 years, but by the administrative division and problems with financing infrastructure repairs on the railway line running through the three voivodships, it was closed [17]. The cancellation of passenger connections was due to a lack of agreement between marshals of three provinces: Wielkopolskie, Lubuskie and Dolnośląskie and long-term negligence in the framework of complex repairs of infrastructure on the above mentioned route. Despite the interest in traveling especially in commuting to schools, workplaces and student's weekend trips to academic cities, the merger was abolished. Undoubtedly, important issue was very low price of the train ticket from Wschowa. Before closing the lines, the cost of travel to Leszno was about 4 PLN, while students could travel even under 2 PLN. The Regional Transport Tariff has made it cheaper to travel to larger cities at convenient interchanges. In the analyzed survey, the interest in the reactivation of passenger rail connections was very clear. In 2013, petitions were signed in Głogów, Wschowa and Leszno to reactivate railway connections on this route. The campaign met with great interest of the inhabitants of these cities [2] and was supported by deputies representing the analyzed region. Among other things, thanks to their involvement, the railway line from Głogów to Leszno by Wschowa was included in the list of railway investments implemented until 2020. [16]. Investments concern revitalization of the track and electrification of the line (Figure 4). In addition, the current investments on PoznańWrocław lines and the "Nadodrzanka" mean that the times of travel to major agglomerations will diminish dramatically. This is one of the reasons to reactivate passenger transport, which due to the ever slimmer offer above the local can keep the transport accessibility of the Wschowa region as good as possible (nowadays from Wschowa can be reached directly to Wrocław and Poznań, Jelenia Góra and Stupsk). If the repair of the railway is completed, the authorities of the provinces will have to agree on the rules of operation of the line, otherwise, despite repairs, it will still not fulfill its role in regional passenger transport. 


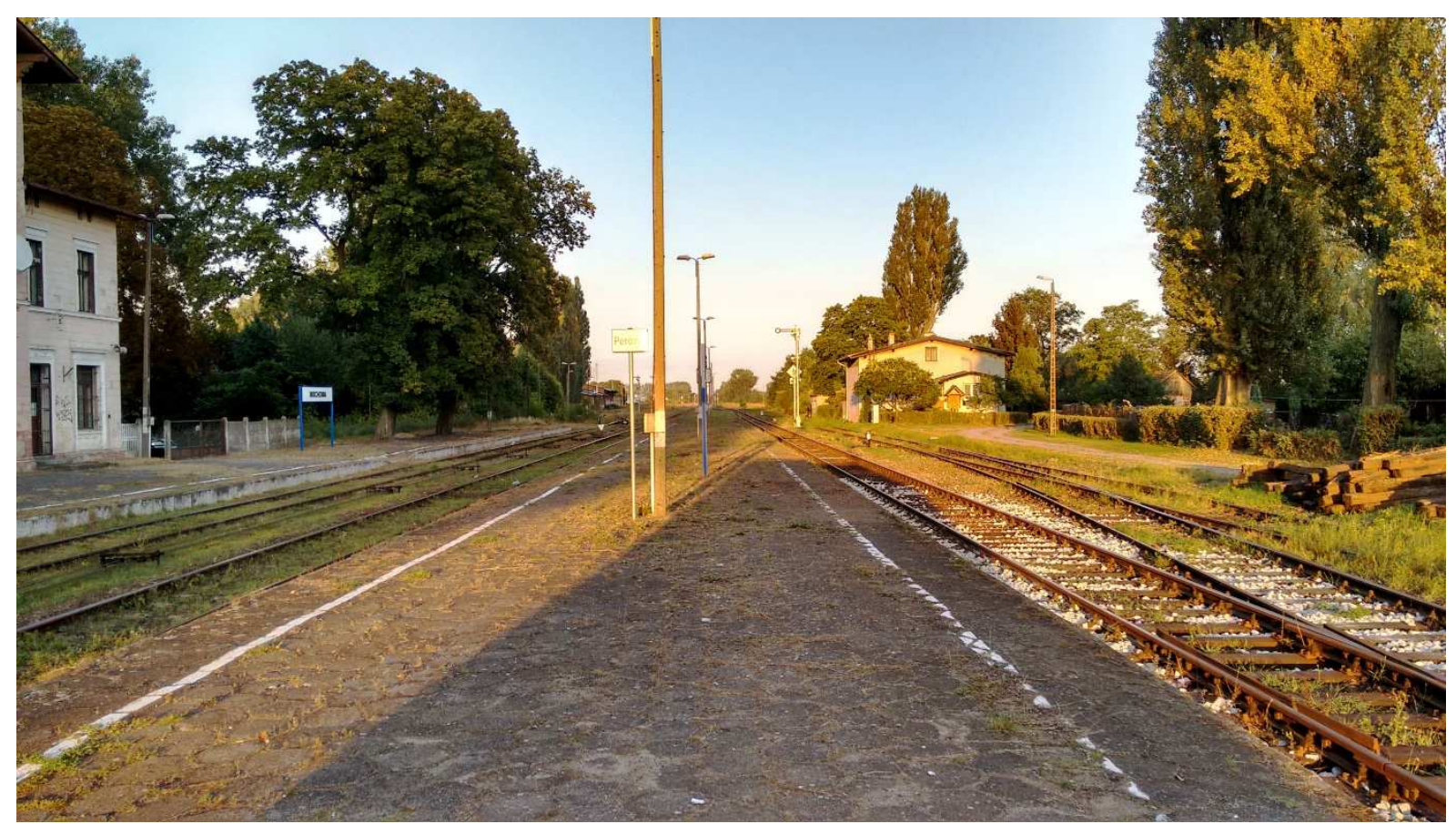

4. Progressive modernization of the railway line Głogów-Wschowa-Leszno (Wschowa station). Source: pic. Author.

\section{Summary}

From the analysis of survey responses, it can be concluded that the young people's in smaller towns condition of travel is to have a car. This aspect frees the high school students from traveling by public transport, which for economic reasons hangs on routes to smaller towns. On the other hand, there is a gradual development of connections from county towns to larger regional centers through mini-bus connections. This is a positive aspect of the deregulation of bus operators' monopoly, and the following process is also evident in the described region [7]. However, the deteriorating position on the market of carriers derived from the PKS structures causes the closure of courses connecting the towns located outside the main transport routes, despite the existence of a law regulating the need to operate the entire network [1]. As a result of this situation, residents use cars, which results in further negative feedback. One example of this is the liquidation of transit courses in the region connecting it with Warsaw, Zielona Góra, Poznań or Kalisz.

One solution to this problem is to increase the frequency of courses between villages in the district. This applied to both courses during off-peak hours on weekdays, as well as connections in the non-working days and holidays. These connections could be carried out by mini-buses. They could function on a "on demand" basis in a similar form as in Western European countries [9]. This would increase the interest in traveling by means of passenger transport [5]. Also in the analysis it was noted that with increased access to passenger courses, interest in using these routes increased (especially at courses to Leszno).

Another chance to change direction and frequency of travel from Wschowa and surroundings may be the reactivation of passenger connections on the railway line GłogówWschowa-Leszno. The willingness of young people to use this form of intercity transport, with the positive view of the provine authorities [11], and the planned modernization and electrification of the railway line, may increase youth mobility and reduce the negative impact of the economic exclusion of the region.

Developed analysis is an attempt of travel preferences characteristics of young people in the border regions, and in this case, high school students from Wschowa and the surrounding area. It shows the most important destinations of young people, which definitely are not other 
places in the home province. This analysis aimed to indirectly show the characteristics of the transport market of the peripheral area located on the border of three provinces, whose formal demarcation in the Wschów region was not anchored in real socio-economic obligations, but the interest of the local administration. In the future, the developed material may become a basis for comparative studies on accessibility, transport marginalization and travel preferences of peripheral areas inhabitants.

\section{Source materials}

[1] Chabierko T., Kretowicz P. Konkurencyjność w lokalnym transporcie zbiorowym a społeczna rola przewozów autobusowych (na podstawie powiatu gorlickiego), Transport Miejski i Regionalny, 2011, 6, 28-35.

[2] Jęczmionka D. „Nie mogę się pogodzić z tym, że tak potraktowano Głogów”, tutajglogow.p1/2013/12/03/nie-moge-sie-pogodzic-z-tym-ze-tak-potraktowanoglogow/, 1.06.2016.

[3] Kaźmierczak-Kałużna I. Mieszkanie jako „miejsce do życia”, Studia Sociologica, 2009, 19, 83-97.

[4] Klan R., Powiat popiera inicjatywę przywrócenia połączeń pasażerskich, http://zw.pl/news/powiat-popiera-inicjatywe-przywrocenia-polaczenpasazerskich,46249, 1.06.2016.

[5] Kretowicz P., Komunikacja lokalna w obszarach peryferyjnych województwa małopolskiego w dobie przemian rynku przewozów autobusowych, Prace Geograficzne, 2010, 124, 131-146.

[6] Kruszyna M. Dostępność połączeń jako kryterium konkurencyjności systemów transportu, Transport Miejski, 1999, 11, 20-25.

[7] Książek S. Przestrzenne następstwa deregulacji transportu autobusowego na przykładzie powiatu świdnickiego, Transport Miejski i Regionalny, 2014, 6, 10-17.

[8] Kusińska A Hierarchia uznawanych wartości jako czynnik kreujący popyt i konsumpcję, Konsumpcja i Rozwój, 2011, 1, 93-106.

[9] Mężyk A. Elastyczne formy transportu publicznego w obsłudze komunikacyjnej regionu, Studia Ekonomiczne. Zeszyty Naukowe Uniwersytetu Ekonomicznego w Katowicach, 2013, 143, 262-270.

[10] Molecki A. Propozycja wskaźnika obrazującego dostępność komunikacyjną jako miernik jakości obsługi mieszkańców, Transport Miejski i Regionalny, 2008, 6, 33-36.

[11]Plan zrównoważonego rozwoju publicznego transportu zbiorowego na sieci komunikacyjnej w wojewódzkich przewozach pasażerskich, 2015, http://bip.lubuskie.p1/264/Plan_Transportowy/\#, 21.11.2015.

[12] Rydzyński P. PKP PLK przymierzają się do modernizacji trasy Ostrów Wlkp. Leszno - Głogów, http://www.rynek-kolejowy.pl/wiadomosci/pkp-plk-przymierzajasie-do-modernizacji-trasy-ostrow-wlkp--leszno--glogow-26882.html, 1.06.2016.

[13] Suszczewicz M. Obszary marginalizacji dostępności komunikacyjnej na pograniczu województw lubuskiego, wielkopolskiego i dolnośląskiego jako przykład problemu zrównoważonego rozwoju obszarów peryferyjnych, Rozwój Regionalny i Polityka Regionalna, 2013, nr 23, 63-75.

[14] Suszczewicz M. Powiat wschowski - potencjał turystyczno-kulturowy, Turystyka Kulturowa, 2013, 4, 68-80.

[15] Szołtysek J., Trzpiot G. Preferencje komunikacyjne studentów jako przesłanki kształtowania programów mobilnościowych, Transport Miejski i Regionalny, 2011, 4, 27-33. 
[16] Szymajda M. Prezydent Leszna chce walczyć o linię kolejową do Głogowa, http://www.rynek-kolejowy.pl/wiadomosci/prezydent-leszna-chce-walczyc-o-liniekolejowa-do-glogowa-75813.html, 15.06.2016.

[17]Zemła J. We Wschowie tęsknią za pociągami, http://kurierkolejowy.eu/aktualnosci/17592/We-Wschowie-tesknia-za-pociagami.html, 1.06.2016. 